\title{
Racism Reflected in Invisible Man
}

\author{
JING Jing \\ Changchun University, Changchun, China \\ PENG Ya-nan
}

Lianghe State Administration Taxation, Yunnan, China

\begin{abstract}
Ralph Waldo Ellison is one of the most distinguished African American writers in the contemporary era. He has a unique writing style because of his unique life experience. His novel Invisible Man won the National Book Award in 1953. He describes the hardship of the black and the racial discrimination the black suffered in the United States in Invisible Man. This paper introduces the racial discrimination in different aspects in America through the narrator's experience, including the narrator's growth process, employment, and politics. He illustrates a lot of hardship the black people meet in different society. The black's rights can not be protected and they need to be humble to the white. Because of the discrimination, the narrator lost himself and began to become an invisible man step by step. These kinds of things are unfair for the black men. They can not realize their social value under such a circumstance. So, Ellison implies that the black men should pay attention to this kind of problem and try to transform their identity from invisible men to visible men.
\end{abstract}

Key words: racial discrimination, Racism, Invisible Man

\section{Introduction}

Ralph Waldo Ellison is a famous black writer and his novel Invisible Man is a famous book in American literature. As an African American writer, he is so concerned about the problem of racism.

Invisible Man was Ellison's masterpiece. It uses the rich metaphor and symbolism to illustrate the racial discrimination in America. And, it makes contribution in American literature. It is the most influential American novel since World War II. Ellison learns from many American and European classical writers and works, and makes Invisible Man become an encyclopedia of American culture and history. Unlike any novel you have ever read, Invisible Man is a richly comic, deeply tragic, and profoundly soul-searching story of one young Negro's baffling experiences on the road to self-discovery.

Ellison spent almost seven years to complete this book. From the bizarre encounter with the white trustee which results in his expulsion from a southern college to its powerful culmination in New York's Harlem. His story moves with a relentless drive: The nightmarish job in a paint factory, the bitter disillusionment with the Brotherhood and its policy of betrayal, the violent climax when screaming tensions are released in a terrifying race riot. This brilliant, monumental novel is a triumph of story telling. It reveals profound insight into every man's struggle to find his true self.

JING Jing, master, lecturer, School of Foreign Languages, Changchun University. PENG Ya-nan, bachelor, public servant, Lianghe State Administration Taxation. 


\section{A Brief Introduction to Racism}

Racism is the discrimination between two different races. Racial discrimination in the United States has been a major issue since the slave era and the colonial era. Legally racist sanctioned rights and privileges for White Americans are not granted to Asian Americans, Native Americans, Latin Americans, and African Americans. The history of American Racism is the slave trade. Since Columbus discovered the New Continent, slave trade had happened. Millions of black men were captured and sailed to American as labors. They suffered hunger, thirsty, and disease. The blacks' social status was very low and their masters took it for granted that they should work all day long and accept all kinds of work they had given to them.

From 1861 to 1865, the bloodiest and most destructive of all the nation's wars, the Civil War between North and South resulted. Black slavery ended in the United States after the Civil War when the North was finally victorious. Slavery was abolished in the 1860s, but its legacy continued. The black was not readily assimilated into the large American culture, especially in the South. This kind of phenomenon still exists until now.

American Racism is reflected in many aspects, including education, employment, voting rights, immigration, citizenship, and so on.

One of the important aspects of the American Racism is education. In the early 100 years after the United States was founded, whether it was public or private school, the white and the black were separated, not co-educational. The situation existed until President Eisenhower era. Even though the law about the situation was already in force, racial discrimination on education still existed. Therefore, there are still most white students who are in good schools.

Another form of American Racism is employment. In America, most of the black are carpenters, miners, soldiers, cleaners, or engaged in heavy industry factory to do some dirty, tiring, and unskilled job. The blacks' wages are generally low. The blacks seldom get into management, engaged in technical work or be a lawyer, doctor, and government officials. Although there has been a large increase now, the number of blacks in the high wage job is still far apart compared with their proportion in the United States.

The third form of racism is living standard. In America, living environment has played a decisive role. It is related to education, employment, service facilities, and so on. The Civil Rights Act of 1968 declared that the blacks have the same opportunities to choose the living environment as the white. The racism in living standard seems to be weakened and disappear. But in fact, it is not improved. In a survey of 119 apartments in Atlanta, only $27 \%$ give equal opportunity for the black and the white. Forty five percent claim that they will give priority to the white. The racial discrimination of living standard divides the American society into two different societies.

\section{Racism Reflected in the Growth Process}

The narrator in Invisible Man is a black man who lives in South America. As we know, the blacks are not slaves now, but they are still poisoned by the ideology of slavery. In their mind, the white are their lord. They have to serve white men without any hesitation. In the period when he was studying in college, the narrator suffered a lot. He was obedient to the arrangement of the teachers in the school and the rule of whites in whites club. When he began to understand the world and himself step by step, American Racism and apartheid policies of the United States make the boy's growth alienation. 
The narrator's growth process experienced the spiritual shock again and again. The poor black youth asked himself again and again, Who am I? Where am I from? How can I be a true man? These were the most abstract questions, but also the most natural questions. In the growth process, the black youth began to know the definition of visibility and invisibility, and transformed himself from visible man to invisible man again and again. From the young's inner change, the author presented the issue of racial discrimination again and again.

In Invisible Man, we can see that the narrator's grandfather warned his family members that, "Son, after I am gone, I want you to keep up the good fight. I never told you, but our life is a war and I have been a traitor all my born days, a spy in the enemy's country ever since I give up my gun back in the reconstruction. Live with your head in the lion's mouth. I want you to overcome'em with yeses, undermine'em with grins, agree'em to death and destruction. Let'em swoller you till they vomit or bust wide open. Learn it to the younguns" (Ellison, 1965, p. 16). The narrator's grandfather's opinion made us ponder. On his grandfather's opinion, the black should keep two identities. On the one side, they should pretend to be a good slave, behaving as their former masters' wish. However, on the other side, they should remember their resentment and bitterness, and fight against this enforced false identity. That was a usual way the blacks will do to deal with the racial discrimination. They just sought a way to protect them but never fight for their rights and identity. From his view, we can see that the racial discrimination in America influenced the black a lot. The black knew that they suffered bitterness and resentment, but they can not change the reality. So, they must wear a mask, so that they can protect himself and live a better life in this unfair world. In the narrator's growth process, we can see that the narrator emphasized submission and humility as the key to the advancement of black Americans. They wanted to get equal human rights to be a real American, but a series of grave insults made them know that they had paid grieving price for them. And even though the view that all men are created equal was put, it seemed that the white were more equal than the black.

\section{Racism Reflected in the Social Life}

After expelled from the college, the narrator began to enter the society. He moved to New York by bus. In the bus, we can see that even though it was vacant, the narrator as a black man can only sit in the end of the row. He met the vet whom he met in Golden Day. The vet told the narrator his felling about the situation of this society and said that this society was so unfair for the black. From the vet's words, we can see that the black man cannot have the some freedom as the white man. The vet also illustrated the fact of racial discrimination, but he was treated as a mental patient. And before the vet got off, he gave the narrator some advice. In the vet's opinion, the black should learn to be their own master. This kind of opinion was very important especially for the black man. But at that time, the narrator did not understand the meaning of the vet's words. When he came to New York, he was so confident. He wanted to obtain the recognition through his efforts and struggle. He wanted to be a visible man and obtained the social status in this industrial society. He believed that he can realize his own value through his efforts. He went to a paint factory with the help of the son of a trustee, Emerson. The narrator thought he can make his dream come true in this factory when he entered the factory.

When he entered the paint plant, he saw a huge electric sign reading "Keep American Pure With Liberty Paint." He was satisfied with everything in the factory, the work environment was free and different races work together. The paint factory was named liberty, and they produced the whitest paint in America. But the way of making this kind of paint was so meaningful. They needed 10 drops to combine. That was just like American 
society, this kind of white can not produce without the blacks. The American prosperity and development can not be separated from the contribution of the blacks. Sometimes, people just saw the final white just like the paint but forgot how it can be so white. Ellison (1965) said in the novel, "Our white is so white you can paint a chunk coal and you would have to crack it open with a sledge hammer to prove it was not white clear through" (p. 195). The meaning of this sentence exactly reflected the situation of the black. In the eyes of the white, the white culture can assimilate black culture just as coal is painted with white paint. We can only see the white from the surface. If someone wanted to see the inner color of the coal, he had to break it with a hammer. The hammer stood for the power the black searches. The way how to produce the white paint demonstrated the way of this society.

He worked hard in this factory, but he did not do the job well. He made the white paint gray and sticky. So, he was sent to basement to work. He had misunderstanding with his master and the labor union. Through the conflict with his master, an old black man, the narrator began to consider about his humility. There was a very important monologue by the narrator in this period. The content of this monologue was that he was be trained be a humble man, and he should bear almost everything. Even though sometimes they bully you, the only way you would do was just leaving. His monologue reflected the current situation of the black man.

In the process of his working in the factory, the narrator was injured because of boiled explosion. When the narrator was sent to the hospital, he was treated as a test object by white doctors. He wanted to be away from the hospital, but the electric shocks made it impossible. He had no choice but lying on the bed. When the doctor asked what his name it, he found that he became a real invisible man. After leaving the hospital, he could not return to the paint factory. And, we can find that it was difficult for an injured black man to find a job in American industrial society.

The narrator suffered a lot in the industrial society, but nobody noticed the narrator's pain and numbness. It seemed that he was like living in another world. He can see every act and every move of the white men, but the white would not notice him. He had been labeled as invisible. The experience in the paint factory made the narrator understand that in this so-called freedom under the factory environment, he still can not change his status as an invisible man. Any free environment did not include him. The American Dream he carried on is so beautiful and so fragile that once the dream touched the reality, it would broken. The narrator began to think about the problem of his dream. But, he finally found that all his thoughts were pipe dream, he was just an invisible man.

\section{Conclusion}

Ralph Waldo Ellison's Invisible Man describes an American black youth without a name and he is not accepted by the society. His experience reflects the phenomenon of racial discrimination in the American society, and his quest for freedom and self nature makes the black call attention to their value and destiny. The author creates a black image who will have self reflection on racial issues. The author describes the problem of racial discrimination in different society through the different stages of the narrator's experience.

In the novel, the author Ellison conducted a comprehensive, real, and profound description and characterization of the social phenomenon of racism. But, unlike many other black writers, Ellison did not have the nationalism tendency. He just describes the common racial discrimination and prejudice through the experience of the narrator. He uses the realistic approach and calm statements to illustrate how racial discrimination engraved deeply in the soul of the Americans. At the same time, Ellison pointed out that in 
America, such a racist crisis of society, it is a very deep social problem. It can not be resolved by racial violence, blindly flatter, or the so-called achievement the blacks get.

\section{References}

Abrams, M. H. (2004). A glossary of literary terms. Beijing: Foreign Language Teaching and Research Press. Bell, B. (1987). The Afro-American novel and its tradition. Amherst: University of Massachusetts Publisher. Chen, J. (1988). A history of English literature. Beijing: The Commercial Press.

Ellison, R. (1965). Invisible Man. London: Penguin Books.

Ellison, R. (1973). Invisible Man. Beijing: Foreign Language Teaching and Research Press.

Gracer, D. (1996). Ralph Ellison's Invisible Man. New Jersey: Research and Education Association.

Manitou, Wordworks. (Ed.). (2000). Modern black writers. Detroit: St. James Press.

Philips, E. C. (1971). Ralph Ellison's Invisible Man. New York: Monarch Press. 